\title{
SINDROMA HIPERVENTILASI
}

\author{
Iwan Sis Indrawanto*
}

Fakultas Kedokteran, Universitas Muhammadiyah Malang, J1. Bendungan Sutami 188 A Sumbersari malang, Lowokwaru, Kota Malang, 65145, Indonesia, (0341) 582060

\begin{abstract}
Abstrak
Sindroma hiperventilasi merupakan gangguan yang sering didapatkan di Unit Gawat Darurat dimana penderita mengeluh sesak dan nyeri dada. Penderita seringkali sangat panik dan ketakutan serta bernafas dengan cepat dan dalam. Tak jarang dokter dan penderitanya menduga terkena serangan jantung/ angina pectoris atau gangguan pernafasan serius, sehingga dilakukan berbagai pemeriksaan yang memberatkan secara finansial dan membuat penderita semakin meyakini bahwa ia mengalami gangguan organik/ fisik. Sindroma ini merupakan gangguan psikiatrik yang pada umumnya terjadi bersamaan/ mengikuti gangguan panik.
\end{abstract}

Kata Kunci: Sindroma hiperventilasi, gangguan panik

\section{Pendahuluan}

Kasus Sindroma Hiperventilasi relatif sering didapatkan di Unit Gawat Darurat (16) Dilaporkan juga bahwa merupakan lebih dari 6\% kasus kunjungan pada dokter spesialis dan bahkan lebih banyak lagi kasus dari praktek dokter umum. (18)

Sayangnya seringkali Sindroma Hiperventilasi tak terdeteksi dengan baik oleh baik psikiater maupun internis, karena seringkali penderita datang dengan gejala gangguan jantung, angina pectoris, asma atau gangguan sistem pernafasan lainnya (18) Seringkali penderita bahkan tak menyadari bahwa dia sedang melakukan overbreathing, dan pemeriksapun sering tak mendeteksi peningkatan kecepatan dan kedalaman respirasi penderita karena perubahannya sangat ringan. Keluhan dan gejala baru timbul bila keadaan tersebut berkelanjutan, sehingga menyebabkan penurunan volume udara alveoli dan tekanan CO2 arteri yang pada akhirnya akan menurunkan kadar bikarbonat darah dan kemudian mulai menampakkan gejala klinis, seperti agitasi, pusing dan parestesi. $(16,18)$

Oleh karena hiperventilasi selain bisa merupakan gejala dari gangguan psikiatris juga dapat merupakan bagian dari gejala penyakit fisik maka pemahaman tentang Sindroma hiperventilasi sangat perlu. Dengan demikian diharapkan penegakkan diagnosis dan penanganannya akan bisa lebih tepat.

\section{Pengertian}

Sindroma hiperventilasi adalah suatu episoda yang ditandai dengan adanya byperpnea berupa pernafasan yang cepat dan biasanya dangkal, yang diikuti dengan sensasi subyektif berupa rasa takut atau panik, serta adanya bermacam-macam keluhan fisik(12), sementara menurut Kaplan dalam Synopsis of Psychiatry edisi ke tujuh dikatakan bahwa pola pernafasan pada penderita sindroma hiperventilasi pada umumnya cepat dan dalam yang berlangsung selama beberapa menit.(13) Episoda serangan sering berulang, dimana episode ulangan bagi penderita sama menakutkannya dengan episode awal. Sindroma hiperventilasi diketahui merupakan manifestasi dari kecemasan atau serangan panik.(12,14,16)
Nancy Hanke mengatakan bahwa sindroma hiperventilasi adalah suatu gangguan psikosomatik yang ditandai dengan adanya pernafasan yang cepat dan dangkal sehingga terjadi penurunan PCO2 arteri dan selanjutnya terjadi gejala-gejala lainnya sebagai akibat penurunan PCO2 tersebut. Sindroma ini penampakannya dramatik. (11)

Gejala sindroma hiperventilasi dapat juga ditimbulkan di laboratorium dengan cara melakukan hiperventilasi atau dengan pemberian infus sodium laktat(12).

\section{Insiden Dan Mortalitas}

Sebagaimana telah disebutkan sebelumnya, bahwa sindroma hiperventilasi relatif sering didapatkan di Emergency Department (16). Dikatakan juga merupakan lebih dari 6\% kasus kunjungan pada dokter spesialis serta lebih banyak lagi kasus di dokter umum.(22) Di Amerika serikat insidens sindroma hiperventilasi mencapai lebih dari 10\% kasus di bagian penyakit dalam.(16)

Insiden pada wanita lebih tinggi dibanding pada lakilaki ya'ni antara 2:1 sampai 7:1.(16)

Meskipun insiden sindroma hiperventilasi pada anggota keluarga derajat pertama adalah tinggi, tetapi faktor genetik masih belum jelas keterlibatan-nya.(16)

Usia terbanyak adalah pada usia 15-55 tahun, meskipun kasus yang dilaporkan ada pada semua usia kecuali bayi.(16)

Pada beberapa penderita, diagnosis sindroma hiperventilasi dapat dengan jelas ditegakkan, tetapi banyak juga kasus yang salah diagnosis, dimana sindroma ini disalah-artikan sebagai gangguan organik.(16)

Bahaya sindroma hiperventilasi adalah terjadinya komplikasi dari jenis pemeriksaan-pemeriksaan medis yang dilakukan terlalu banyak dan seharusnya tak perlu (misalnya pemeriksaan angiografi). Selain itu juga komplikasi sebagai akibat dari penanganan yang salah. Konsekwensinya adalah bukan hanya kondisi sindroma hiperventilasinya yang menimbulkan perasaan tak enak pada penderita, tetapi juga karena biaya pemeriksaan medis yang tinggi sebagai akibat pemeriksaan yang dilakukan untuk menyingkirkan diagnosis lainnya yang lebih serius.(16) 
Meskipun demikian, dikatakan bahwa angka mortalitas sindroma hiperven-tilasi adalah sangat kecil.(16)

\section{Psikopatologi}

Keadaan hiperventilasi serta kelainan fungsi otonomik lainnya adalah meru-pakan hal yang biasa terjadi sebagai respons normal terhadap rasa takut atau cemas akut. $(1,12)$ Namun penderita sindroma hiperventilasi cenderung lebih menekankan keluhan fisiknya dibanding situasi stresnya, dan cenderung menjadi gangguan berulang serta bersifat kronis, oleh karena itu keluhan utama yang sering dikeluhkan penderita hiperventilasi adalah adanya 'ketidak-beresan' pada dada atau jantung (kecemasan difokuskan pada fisik yaitu pada gangguan fungsi organ vital). Karena itu penderitapenderita ini seringkali berobat justru pada internist atau cardiologist. (12)

Mekanisme terjadinya sindroma hiperventilasi hingga saat ini masih belum jelas, tetapi ada beberapa teori. Dari segi penjelasan psikodinamika, dikatakan bahwa pada penderita sindroma hiperventilasi terjadi penonjolan disfungsi fisik untuk menggantikan "misfungsi personal",(12). Namun penjelasannya tidaklah sesederhana itu. Dikatakan bahwa memang keadaan yang memicu emosi dapat menyebabkan pernafasan per menit meningkat, yang pada individu-individu tertentu berkembang menjadi serangan sindroma hiperventilasi. Sayangnya seringkali penderita tak bisa mengenali stres yang mana yang menyebabkannya. Memang ada beberapa penderita yang menyadari bahwa kondisi stres tertentu mendahului terjadinya serangan, misalnya akan mempresentasikan sesuatu dimuka orang banyak. Akan tetapi pada banyak kasus menunjukkan bahwa penderita sebelumnya mampu melakukan hal semacam itu dengan baik tanpa terjadi serangan panik dan hiperventilasi. (1) Louis Vachon mengingatkan bahwa problema psikologis penderita sindroma hiperventilasi adalah kompleks. Seringkali pada penderita sindroma hiperventilasi kronis didapatkan kecemasan yang timbul bersamaan dengan psikopatologi lainnya, dan stres yang dikeluhkan penderita seringkali justru bukan sumber distresnya.(12)

Menurut teori yang lain, diantaranya telah disepakati bahwa pada suatu populasi, stres tertentu dapat memicu respons respirasi yang berlebihan. Stres-stres tersebut antara lain adalah distres emosional, sodium laktat, kafein, isoproterenol, kolesistikinin, dan CO2.(2,3,21,7,8,16,20). Dari suatu studi dimana dilakukan pemberian infus laktat pada penyandang gangguan panik yang sedang tenang, dapat memicu terjadinya serangan panik. Dari hasil studi tersebut, pada $80 \%$ dari penyandang gangguan panik terjadi serangan panik, dan pada obyek yang normal hanya terjadi 10\%. Dari $50 \%$ responder laktat mengalami hiperventilasi akut sebagai bagian dari reaksi panik.(16)

Penjelasan lainnya tentang terjadinya sindroma hiperventilasi adalah pada mekanisme pernafasan. Penderita sindroma hiperventilasi cenderung menggunakan thoraks atas untuk bernafas, bukannya diafragma, sehingga menyebabkan terjadinya overinflasi paru dan bersifat kronis. Pada orang normal, disaat istirahat tidal volume berada pada $35-45 \%$ vital capacity. Hiperinflasi paru diluar batas tersebut tertahan oleh elastic recoil dinding dada dan volume inspirasi diluar level tersebut merupakan usaha ekstra yang tampak sebagai kondisi dyspneu. Pada saat penderita Sindroma hiperventilasi mengalami stres, terjadi peningkatan kebutuhan untuk menarik nafas dalam-dalam, namun hal tersebut terhambat oleh elastic recoil dinding dada, sehingga individu berusaha memenuhi peningkatan kebutuhannya tersebut dengan usaha ekstra, diantaranya dengan meningkatkan frekwensi nafas per menit, yang teramati sebagai dyspneu. Sensasi dyspneu ini menimbulkan kecemasan yang akan memicu individu tersebut untuk berusaha bernafas lebih dalam sehingga terjadilah hiperventilasi. Demikianlah selanjutnya kejadiannya berulang kembali bagaikan suatu lingkaran.(16)

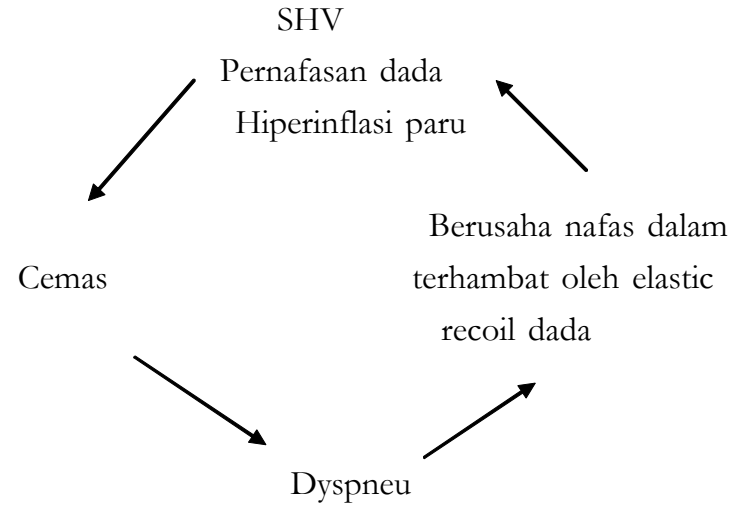

Dikatakan juga bahwa kebiasaan bernafas yang salah juga merupakan faktor penyebab. Pengaruh budaya bahwa perut yang kecil dan rata adalah body image yang baik, sehingga banyak orang berusaha bernafas dengan dada. Griefperiod, masa 'anticipating harm', juga dapat menyebabkan pembentukan pola pernafasan dangkal, yang pada saatnya akan menjadi serius dan menimbulkan serangan sindroma hiperventilasi.(1)

Cowley mengatakan bahwa Sindroma hiperventilasi dan gangguan panik adalah dua keadaan yang saling berhubungan erat. Kedua gangguan ini sering didapatkan terjadi bersamaan. Keduanya sama-sama bersifat serius, tetapi juga dikatakan sama-sama mudah penanganannya. Hubungan yang erat pada kedua jenis gangguan tersebut juga ditunjukkan oleh adanya kesamaan dalam hal gejala, patofisiologinya, serta timbulnya serangan hiperventilasi pada saat terjadi episoda panik. Hal ini terjadi baik pada serangan panik yang ditimbulkan dengan sengaja di laboratorium, maupun serangan panik spontan. Selain itu, kedekatan antara kedua jenis gangguan tersebut juga dapat disimpulkan dari timbulnya serangan panik pada penderita gangguan panik (yang sedang diluar serangan) saat melakukan hiperventilasi. Kesamaan lainnya adalah bahwa keduanya sama-sama membaik dengan dilakukannya latihan pernafasan. (4)

Newton mengatakan bahwa penyandang gangguan panik dan sindroma hiperventilasi cenderung mempunyai nilai ambang yang rendah terhadap respons fight or flight. Meskipun stimulus pemicu terjadinya kedua macam gangguan tersebut serta respons stresnya cenderung sama, namun manifestasi gejala kedua gangguan tersebut berbeda. Pada penderita sindroma hiperventila-si gejalanya terfokus pada keluhan somatik sesuai dengan perubahan fisiologis 
yang diakibatkan oleh hiperventilasi. Sedangkan pada gangguan panik cenderung bermanifest dalam bentuk keluhan psikiatris, seperti takut mati, atau kecenderungan terjadinya claustrophobia.(16)

\section{Fisiopatologi}

Penderita sindroma hiperventilasi bernafas dengan cepat dan dangkal yang umumnya tak disadari oleh penderita sendiri. Keadaan ini mengakibatkan CO2 banyak keluar sehingga CO2 tubuh menurun, dan sebagai akibatnya, maka darah menjadi terlalu bersifat basa (blood alkalosis).(9,14,18) Kondisi alkalosis menyebabkan arteri vasokonstriksi dan mengakibatkan aliran darah tertahan. Selanjutnya $\mathrm{O} 2$ tak terangkut dengan baik ke jaringan atau organ. Oleh karena itu, pasokan O2 ke otakpun menurun bahkan hingga 50\%, serta terjadi penurunan aliran darah ke otak yang mencapai $2 \%$ untuk setiap $\mathrm{mmHg}$ penurunan pCO2.(20) Sebagai akibat penurunan pasokan darah ke otak tersebut, terjadilah gejala awal, berupa pandangan kabur, yang disusul merasa pusing/ dizzy, rasa ringan di kepala, tegang, cemas, jittery, dan nervous, sampai penderita menjadi gelisah dan serasa ingin menangis, lemah dan bingung serta agitasi.(16,18,20) Banyak penderita mengeluhkan adanya gejala depersonali-sasi dan halusinasi visual.(16) Karena kebutuhan yang amat sangat terhadap O2, penderita menjadi merasa tercekik. Selanjutnya bila keadaan ini tak teratasi, otak semakin 'kacau' dan memberikan perintah yang salah sehingga penderita menjadi lepas kendali serta berperilaku kacau, dan merasa ketakutan. Rasa takut ini menyebabkan sistem syaraf berreaksi melepas adrenalin yang menyebabkan terjadinya dilatasi pupil dan wajah serta tangan dan kaki menjadi dingin dan kaku (numb), gemetar serta berkeringat dingin. Juga terjadi jantung berdebar, menyebabkan tekanan darah meningkat dan penderita menjadi lemah bahkan pingsan. Juga bisa timbul rasa nyeri dada, yang tentunya berbeda dengan nyeri dada angina, dimana pada Sindroma hiperventilasi nyeri dada disebabkan penderita melakukan pernafasan dada secara berlebihan. $(16,24,18)$

Kondisi terjadinya pergeseran ke kiri kurva disosiasi $\mathrm{HbO} 2$ dan vasokon-striksi karena menurunnya $\mathrm{pCO} 2$, pada penderita penyakit jantung koroner dapat menyebabkan iskemia miokardial. Hal ini berbahaya bagi penderita usia tua, yang kemungkinan menderita stenosis arteri koroner.(16)

Selain itu, timbulnya refleks vasokonstriksi seperti yang telah disebutkan diatas, juga mempengaruhi kulit dan usus, yang bermanifestasi dalam bentuk perut kembung, bleching, flatus, dan peningkatan tekanan epigastrium karena aerophagia.(16)

Kondisi alkalosis juga membuat tubuh berreaksi membentuk mekanisme buffer, untuk mempertahankan $\mathrm{pH}$ mendekati normal. Reaksi ini menyebabkan terjadinya perubahan metabolik akut yang disebabkan oleh pergeseran komposisi beberapa elektrolit intraseluler dan adanya peningkatan binding protein selama terjadinya alkalosis respiratorik. Keadaan ini menyebabkan terjadinya hipokalsemia. Kondisi hipokalsemi akut dapat menyebabkan tetani, spasme karpopedal, twitching otot, munculnya tanda Chovstek dan Trousseau, serta pada gambaran EKG terdapat pemanjangan interval QT.(16) Bila kondisi alkalosis ini tak segera terkoreksi, keadaan akan semakin memburuk dan bisa berakibat fatal. Sementara itu, hipokalemik bisa juga terjadi, meskipun jarang, dimana hal ini dapat menyebabkan kelemahan umum.(16)

Sering juga terjadi hipopospatemia akut dan kondisi ini memperburuk parestesi serta kelemahan umum yang terjadi. Dilaporkan juga bahwa paraestesi lebih sering terjadi pada ekstremitas atas dan umumnya bilateral. Pada kasuskasus paraestesi yang unilateral, $80 \%$ kasus mengena pada sisi kiri. $(8,16)$

Pada duapertiga penderita sindroma hiperventilasi kronis menunjukkan penurunan $\mathrm{pCO} 2$ persisten dengan kompensasi ekskresi HCO3 per renal, agar $\mathrm{pH}$ darah terkoreksi sampai mendekati normal. Usaha kompensasi yang kronis ini akan mempercepat timbulnya gejala bilamana mereka mengalami stres tambahan yang memicu terjadinya hiperventilasi. Hal ini disebabkan karena cadangan asam basa fisiologis mereka sedikit.(16)

Gejala rasa baal disekitar mulut dikatakan sering juga terjadi, begitu juga keluhan mulut lainnya berupa mulut kering karena penderita cenderung bernafas dengan mulut.(16)

Seperti telah dijelaskan diatas, pemberian infus laktat pada penyandang gangguan panik yang sedang tenang dapat memicu terjadinya serangan panik, dimana 50\% dari responder laktat ini mengalami hiperventilasi akut sebagai bagian dari reaksi panik. Dari studi ini didapatkan bahwa ternyata level laktat pada penyandang gangguan panik lebih tinggi dan bertahan lebih lama dalam darah dibanding kontrol. Hal ini menunjukkan keterlibatan metabolisme yang abnormal dari laktat sebagai patofisiologinya, meskipun abnormalitasnya belum terrinci.(16)

\section{Diagnosis}

Pada Pedoman Penggolongan Diagnosis Gangguan Jiwa III (PPDGJ III), sindroma hiperventilasi dikatakan sebagai psychogenic byperventilation, dan digolongkan dalam disfungsi otonomik somatoform sistem respiratori. Disebutkan dalam PPDGJ III tersebut bahwa gejala yang tampak pada penderita disfungsi otonomik somatoform adalah keluhan yang seolah terjadi gangguan pada sistem atau organ yang sebagian besar atau seluruhnya diinervasi dan dikendalikan oleh sistem syaraf otonomik. Gejalagejalanya pada umumnya ada dua macam, yaitu yang menunjukkan gangguan fisik organ atau sistem mana yang terlibat. Macam pertama, adalah yang terbanyak, ditandai adanya tanda obyektif terjadinya bangkitan otonomik, seperti palpitasi, berkeringat, flushing, serta tremor. Macam kedua, adalah ditandai adanya gejala-gejala yang lebih idiosinkras, subyektif, dan tidak spesifik, seperti perasaan sakit atau nyeri, rasa terbakar, berat, dan rasa kembung atau distended, yang merujuk pada organ atau sistem tertentu dari penderita sebagaimana juga yang terjadi pada sistem otonomik. Diagnosanya meliputi kombinasi keterlibatan sistem otonomik yang nyata, keluhan tambahan subyektif yang non spesifik, dan secara persisten keluhan mengarah pada organ atau sistem tertentu sebagai sumber penyebab terjadinya gangguan serta gejala klinisnya.(5)

Banyak penderita gangguan ini, mengalami stres psikologik, atau kesulitan dan problema yang timbulnya berkaitan dengan gangguan ini; tetapi hal tersebut tidak 
proporsionil pada penderita meskipun penderita memenuhi kriteria diagnosis yang lengkap.(5)

Pada beberapa dari gangguan-gangguan ini, dapat juga terjadi beberapa kelainan kecil fungsi fisiologis, seperti biccough, flatulence, dan hiperventilasi, tetapi kelainan-kelainan ini bukan satu-satunya penyebab terjadinya gangguan utama fungsi fisiologis organ atau sistem yang terkait.(5)

Sebagai acuan diagnosis, PPDGJ III memberikan kriteria atas disfungsi otonomik somatoform sebagai berikut (5)

1. Adanya gejala bangkitan otonomik, seperti palpitasi, berkeringat, tremor, flushing, yang persisten dan mengganggu penderita,

2. Adanya gejala-gejala subyektif tambahan sesuai dengan organ atau sistem yang terlibat.

3. Terdapat preokupasi dan distres tentang kemungkinan terjadinya gangguan serius (tetapi seringkali tidak terpastikan) pada organ atau sistem tersebut, yang tidak berrespons terhadap penjelasan dan reassurance yang berulang-ulang oleh banyak dokter.

4. Tidak didapatkan adanya bukti-bukti kelainan struktur atau fungsi organ atau sistem yang dikeluhkan.

Menurut Newton, sindroma hiperventilasi bisa terjadi dalam bentuk akut maupun kronis. Yang akut jarang terjadi (hanya 1\%) dan lebih mudah terdiagnosis, karena penampakan klinisnya dramatis, sedangkan sindroma hiperventilasi kronis sering terjadi bersamaan dengan gejala gangguan pernafasan, gangguan jantung, neurologis atau gangguan gastro intestinal dimana gangguan-gangguan ini bisa juga terjadi bukan karena hiperventila-sinya, tetapi oleh gangguan fisik yang lain. $(16,18)$ Selain itu, penderita hiperventilasi kronis pada awalnya nampak seperti menunjukkan gejala gangguan organik serius, tetapi kemudian tampak bahwa gejala-gejalanya tersebut atipikal.(16)

Sindroma hiperventilasi perlu dicurigai pada penderita muda yang tidak mempunyai faktor resiko gangguan jantung dan datang dengan keluhan nyeri dada, terutama bila disertai keluhan paraestesia serta keluhan spasme karpopedal. Tetapi dalam menegakkan diagnosanya harus hati-hati karena banyak kemungkinan adanya gangguan organis yang serius sebagai penye-babnya.(16)

Untuk menegakkan diagnosis, dibutuhkan anamnesis riwayat penyakit yang teliti serta pemeriksaan fisik dan bila perlu test laboratoris untuk menyingkirkan kemungkinan penyebab organis. $(12,16)$

\section{Anamnesis}

Pada penderita sindroma hiperventilasi akut, pada anamnesa didapatkan bahwa umumnya setiap terjadi serangan disertai dengan terjadinya agitasi dan kecemasan. Seringkali didapatkan adanya riwayat nyeri dada mendadak, dyspnea, dan gangguan neurologis (pusing, perasaan lemah, dan paraestesi) yang didahului oleh adanya situasi stres emosional.(16)

Penderita juga banyak mengeluh merasa tercekik, bingung, gelisah, bahkan kadang-kadang terdapat keluhan depersonalisasi serta halusinasi visual.
Pada penderita sindroma hiperventilasi kronis didapatkan riwayat keluhan-keluhan fisik yang bermacammacam dan berulang, serta pada umumnya penderita telah menjalani berbagai macam pemeriksaan medis, dan telah didiagnosis bermacam-macam. Dari anamnesa yang teliti didapatkan juga bahwa banyak diantara penderita hiperventilasi kronis mengalami gangguan obsesi kompulsi, mengalami hambatan seksual dan problema dalam perkawinan, dan umumnya memiliki tingkat adaptasi yang rendah terhadap stres.(16)

\section{Pemeriksaan fisik}

Dari pemeriksaan fisik pada penderita hiperventilasi akut, didapatkan adanya tachipnea, dan hiperpnea yang jelas. Juga didapatkan nyeri dada yang atipikal, meskipun kadangkadang menyerupai serangan angina. Serangan ini cenderungberlangsung lama hingga berjam-jam, tidak seperti serangan angina pektoris yang hanya berlangsung beberapa menit. Keluhan nyeri dada ini menurun dengan dilakukannya aktifitas fisik, bukannya justru terpicu seperti halnya angina, serta tidak membaik dengan pemberian nitroglycerine. Seringkali didapati adanya dispnea, agitasi, pusing, dan parestesi, dimana hal ini merupakan gambaran yang khas pada penderita muda dan sehat yang mengalami hiperventilasi.

Kadang-kadang bisa timbul wheezing paru-paru karena terjadinya bron-chospasme akibat hipokarbia. $(22,8,9,16,23,18)$

Pada palpasi dinding dada, terraba adanya tenderness, terutama pada thoraks bagian atas, yang terjadi karena kelemahan ligamen dan otot dinding dada.(16)

Bisa juga didapatkan spasme karpopedal, yang disebabkan oleh karena terjadinya hipokarbia akut yang mengakibatkan turunnya level kalsium serta pospat yang terionisasi, yang pada gilirannya akan menyebabkan kontraksi tangan dan kadang-kadang juga pada kaki.Kondisi hipokalsemik ini kemungkinan juga dapat menyebabkan terjadinya tanda Chovstek dan Trosseau.(16)

Newton mengatakan bahwa kadang-kadang bisa didapatkan tremor, midriasis, pallor, tachycardia dan manifestasi kecemasan, bahkan seringkali juga didapatkan adanya halusinasi dan depersonalisasi.(16)

Pada sindroma hiperventilasi kronik, didapatkan suatu hal yang khas ya'ni adanya keluhan yang banyak tanpa disertai tampilan fisik yang sesuai. Pada observasi, didapatkan penderita nampak bernafas 'desah' dengan frekwensi 2-3 kali tiap menitnya. Seperti halnya pada penderita Sindroma hiperventilasi akut, pada palpasi terraba adanya tenderness dinding dada.(16)

Dalam pengamatan, penderita sindroma hiperventilasi tampak pola pernafasannya normal/ tidak terlalu overventilasi saat dilakukan wawan-cara psikiatris. Dengan berbicara teratur, dengan sendirinya terjadi pengaturan volume pernafasan. Yang perlu ditangani adalah kondisi cemas/ panik yang merupakan underlying factor terjadinya sindroma.(12)

\section{Laboratoris :}

Karena gejala klinisnya meragukan, maka tidak jarang dilakukan pemeriksaan-pemeriksaan yang berlebihan dan mahal untuk mencari penyebab organiknya.(16) 
Untuk menyingkirkan hipoksia sebagai penyebab hiperventilasi, sebaiknya dilakukan pengukuran saturasi $\mathrm{O} 2$, karena pada penderita sindroma hiperventilasi didapatkan saturasi $\mathrm{O} 2$ dalam darah adalah normal. Bila dicurigai adanya asidosis, perlu dilakukan analisa gas darah, dimana analisa ini juga dapat digunakan untuk mengkonfirmasi adanya alkalosis respiratorik kronis dengan kompensasi pada sebagian besar kasus, dimana pada penderita sindroma hiperventilasi didapatkan $\mathrm{pH}$ nya mendekati normal, dengan pCO2 dan pHCO3 menurun.(16)

\section{Studi Imaging}

Pemeriksaan radiografi dada hanya dilakukan apabila didapatkan resiko tinggi adanya kelainan jantung atau paru, atau apabila pada pemeriksaan fisik didapatkan kelainan yang mengarah ke kelainan organik dada. Pada kasus-kasus sindroma hiperventilasi yang sudah jelas, tidak dianjurkan dilakukan pemeriksaan radiologis, karena seringkali didapatkan gambaran yang normal, bahkan gambaran normal inipun seringkali didapatkan pada kasus-kasus yang meragukan.(16)

\section{Pemeriksaan lainnya}

\section{- Elektrokardiografi}

Dengan pemeriksaan elektrokardiografi umumnya didapatkan perubahan pola, antara lain interval QT memanjang, depresi / elevasi ST, dan terbaliknya gelombang T.(16)

\section{- $\quad$ Skrining toksikologi.(16)}

\section{Diagnosis banding}

Kondisi hiperventilasi dengan gejala klinis yang jelas dapat saja terjadi pada berbagai macam gangguan fisik, mulai dari keadaan patologi batang otak (misalnya karena trauma), atau adanya gangguan metabolisme (misalnya, ketosis diabetikum), hingga penyakit-penyakit kardiopulmoner (misalnya, emboli pulmoner) dan keracunan bahan eksogen (misalnya, salisilat). Untuk membantu memperjelas diagnosis banding, diperlukan penelusuran riwayat penyakit, pemeriksaan adanya gejala dan tanda-tanda klinis lainnya, serta test-test laboratorium sesuai dengan gangguan organik yang dicurigai.(12,16,23)

\section{Penanganan}

Penanganan terhadap sindroma hiperventilasi bisa berupa perawatan pra rumah sakit, perawatan di rumah sakit, dan perawatan pasca rumah sakit.

\section{Perawatan pra rumah sakit}

Pada penanganan awal penderita hiperventilasi dengan kausa yang belum jelas, dianjurkan agar segera merujuk penderita ke rumah sakit untuk pemeriksaan yang lebih lengkap. karena banyaknya kemungkinan penyebab gangguan fisik yang serius. (16)

Newton mengatakan bahwa apabila etiologi organis yang lebih serius belum tersingkirkan, tidak direkomendasikan untuk menyuruh penderita bernafas dalam kantung kertas, karena pada penderita infark miokard akut, tehnik ini dapat menyebabkan kematian. Juga pada penderita hiperventilasi kausa organik lainnya seperti oedema pulmo atau asidosis metabolik, peningkatan pCO2 dan penurunan $\mathrm{O} 2$ bisa membahayakan. Selain itu, Newton juga mengatakan bahwa, melakukan teknik pernafasan dalam kantung kertas seringkali tak berhasil karena seringkali penderita kesulitan melakukannya, juga karena CO2 sendiri merupakan pemicu kimia terjadinya kecemasan pada penderita-penderita ini.(16

\section{Perawatan di Rumah Sakit}

Menurut Kaplan, terapi awal yang dianjurkan adalah dengan bernafas dalam kantung kertas, menghisap kembali CO2 yang dihembuskan. (12). Tentunya hal ini hendaknya dilakukan setelah penyebab organik telah disingkirkan seperti telah disebutkan diatas. Adapun tehnik melakukan pernafasan dalam kantung kertas adalah sebagai berikut : (9)

Tangkupkan kantung kertas menutupi hidung dan mulut dengan rapat.

Bernafaslah perlahan-lahan, dengan menghirup dan menghembuskan udara didalam kantung kertas, sedikitnya 10 kali.

Kemudian lepaskan kantung kertas dan bernafaslah dengan cara normal diluar kantung kertas beberapa menit.

Ulangi lagi prosedur diatas beberapa kali sampai gejalagejala mereda.

Bila setelah keadaan membaik kemudian terjadi gejalagejala kembali, ulangi lagi proses diatas.

Setelah keadaan kritis berhasil terlewati (dan kausa organis tersingkirkan), dapat dilakukan simple reassurance serta diberikan penjelasan pada penderita tentang bagaimana hiperventilasi dapat menyebabkan terjadi-nya gejala-gejala klinis pada penderita. Bila perlu diberikan demonstrasi dengan cara penderita secara sengaja dibimbing untuk melakukan hiperventilasi dan bersama pemeriksa memantau apa yang terjadi. Cara ini biasanya terbukti efektif. (16)

Penanganan dengan cara menekan toraks bagian atas secara fisik dan kemudian meminta penderita menghembuskan nafas secara maksimal. Hal ini dapat menurunkan hiperinflasi paru sebagai akibat dari kecenderungan penderita untuk bernafas dengan menggunakan toraks atas sehingga paru-parunya menunjukkan kondisi hiperinflasi selama siklus pernafasan.(16)

Langkah yang berikutnya adalah membimbing penderita bernafas dengan menggunakan perut, dengan diafragma. Bernafas dengan cara ini, sangat memperbaiki kondisi dispnea dan bahkan dapat memperbaiki kondisi klinis lain yang menyertainya. Untuk membiasakan hal ini, penderita sebaiknya dirujuk ke fisioterapis guna dilatih teknik bernafas dengan diafragma.(16)

Penggunaan preparat Benzodiazepin dikatakan cukup efektif untuk penderita ini, tetapi dibutuhkan waktu yang cukup lama. Juga jenis-jenis terapi yang bertujuan mengurangi stres, pemberian preparat beta bloker, serta antidepresan trisiklik terbukti efektif menurunkan intensitas dan frekwensi terjadinya serangan sindroma hiperventilasi. $(8,16,19)$

Untuk kasus-kasus hipeventilasi berat, dapat dilakukan sedasi dengan bahan- bahan kimia. Meskipun dikatakan 
bahwa cara ini cukup efektif dan manusiawi, penggunaan dalam jangka waktu lama tidak dianjurkan di Emergency Room.(16)

\section{- Perawatan Pasca Rumah Sakit}

Secara logika, hal paling mudah dilakukan adalah menghindari keadaan- keadaan yang menimbulkan kecemasan. Tetapi hal ini tentu akan sangat membatasi gerak penderita. (1)

Penderita sebaiknya dirujuk ke psikiater, psikolog atau ke dokter keluarga sebagai rawat jalan selanjutnya.

Sebagaimana disebutkan diatas, pemberian benzodiazepin, antidepresan trisiklik atau beta bloker cukup efektif untuk pengobatan penderita sindroma hiperventilasi, meskipun memerlukan waktu cukup lama dan harus dilakukan oleh psikiater. Jenis antidepresan clomipramine dikatakan lebih poten dari imipramine. Imipramine adalah 5-HT uptake blocker yang lemah, sehingga diperlukan dosis yang besar untuk bisa mencegah eksaserbasi terjadinya serangan panik.(8)

Banyak diantara penderita sindroma ini juga menderita gangguan lainnya seperti agorafobi, yang kemungkinan bisa mendahului gejala klinis dari Sindroma hiperventilasi. Dikatakan bahwa penanganan terhadap gangguan primernya ini dapat memperbaiki sindroma hiperventilasi.(8)

Joseph Goldberg mengatakan bahwa selain ketiga macam medikasi diatas, pemberian anti depresan lainnya seperti golongan SSRI atau MAOI dengan jangka waktu relatif panjang juga efektif untuk pengobatan.

Disamping itu disarankan pula penggunaan Cognitive Behavioural Therapy sebagai terapi tambahan atau alternatif. Terapi ini diarahkan pada koreksi hiperventilasi dengan cara mengajarkan tehnik pernafasan diafragma dan relaksasi. Juga Cognitive Behavioural Therapy digunakan untuk menghilangkan avoidance behaviour, serta mencegah kekambuhan. Hasil penelitian mengatakan bahwa hasil terapi dengan menggunakan keduanya cukup baik bagi sebagian besar penderita. Pada penelitian di multisenter lainnya, didapatkan bahwa kombinasi medikasi yaitu pemberian imipramine dan terapi perilaku menunjukkan respons per-baikan $90 \%$ pada penderita yang menjalani terapi selama 12 bulan. Dr. Liebowitz menyarankan terapi dimulai dengan salah satu (medikasi atau terapi perilaku) lebih dulu, dan kemudian bila respons inisial kurang memadai dapat dilakukan kombinasi keduanya. Sedang untuk mengu-rangi kemungkinan terjadinya kekambuhan, Dr.Liebowitz menganjurkan terapi lanjutan selama 6-8 bulan setelah bebas serangan atau terbebas dari fobia menghindar. Saat medikasi, dilakukan penurunan dosis secara perlahan dalam waktu mingguan hingga bulanan, dan penderita diikuti secara ketat untuk memantau terjadinya kekambuhan panik serta kemungkinan timbulnya withdrawal.(8)

Diluar serangan akut hiperventilasi, penderita gangguan cemas kronis seringkali mempunyai kebiasaan over ventilasi dengan seringkali melakukan desah yang dalam. Penderita harus diingatkan agar menghindari kebiasaan ini. Penderita diajarkan bernafas dengan hidung, bukan dengan mulut, dengan demikian minute volume terbatasi. (12)

\section{Komplikasi}

Komplikasi terutama diakibatkan oleh prosedur diagnostik invasif seperti angiografi, atau oleh hal-hal yang diakibatkan oleh hiperventilasi secara tak langsung, seperti trauma yang terjadi karena terjatuh waktu pingsan saat serangan hiperventilasi.(16)

\section{Prognosa}

Penderita Sindroma Hiperventilasi cenderung mengalami eksaserbasi berulang kali selama hidupnya. Suatu penelitian melaporkan bahwa pada satu seri nyeri dada dari 45 penderita yang diperiksa dengan angiografi dan didapatkan gambaran koroner yang normal, ternyata kemudian terdiagnosis sindroma hiperventilasi. Setelah lebih dari 3,5 tahun diikuti, ternyata didapatkan $60 \%$ dari penderitapenderita tersebut masih sering datang kembali dengan keluhan nyeri dada dan $40 \%$ menjalani rawat inap kembali untuk memastikan tidak adanya infark miokard. Pada anakanak, gangguan Sindroma hiperven-tilasi cenderung menetap sampai dewasa.(16)

Wheeler mengatakan bahwa pada penelitian-penelitian awal, serangan panik dikategorikan sebagai Effort Syndrome, dimana dikatakan bahwa $90 \%$ penderita masih menunjukkan gejala setelah 20 tahun kemudian, meskipun sebenarnya secara sosial mereka mampu berfungsi dengan baik.(10)

Sebagai penutup dari tulisan ini, sesuai dengan pernyataan Kaplan, dalam menangani kasus sindroma hiperventilasi, berlaku kaidah terapi seperti pada penderita Gangguan Konversi, ya'ni terapist jangan mensuport keyakinan penderita akan adanya kelainan fisik, tetapi juga harus berhati-hati agar jangan sampai merusak hubungan terapeutis dengan penderita. Dengan bijaksana dan hatihati terapist merancang sesion terapi dengan berpusat pada distres penderita, serta harus berorientasi pada eksplorasi yang meliputi semua aspek situasi kehidupan penderita. Hubungan terapeutik yang suportif dan dependable, serta dikombinasi dengan penggunaan antidepresan/ anticemas secara hati-hati dapat menurunkan kecemasan dan frekuensi serangan sindroma hiperven-tilasi.(12)

Sayangnya, seringkali penanganan penderita sindroma hiperventilasi gagal menghilangkan keyakinan adanya kelainan somatik, manakala keluhan/ kondisi fisik sudah merupakan fokus dominan dalam kehidupan penderita.(12)

\section{Daftar Pustaka}

Anderson, BA: Panic and Hyperventilation Syndrome, Healing Panic, How To Treat Your Own Panic Disorder, http://www'healingpanic.com/chap2.html, 1995-1998.

Biber,B, Alkin.T: Panic Disorder Subtypes: Different Responses to CO2 Challenge, American Journal Psychiatry 156:5, May 1999, 739- 748

Ben-Zion,IZ, et al: Enhancement of CO2-Induced Anxiety in Healthy Volunteers With The Serotonin Agonist Metergoline, American Journal Psychiatry, 156: 10, October,1999, 1635-1637.

Cowley DS, Roy-Byrne PP: Hyperventilation and panic disorder, American Journal Med 1987 Nov;83(5): 92937, PubMed QUERY, http://www.ncbi.nlm.nih.gov/ 
htbinpost/Entrez/query? $\mathrm{db}=\mathrm{m} \&$ form $=6 \& \mathrm{Dopt}=$ r\&uid=88046907, 1999.

Departemen Kesehatan RI. Direktorat Jenderal Pelayanan Medik: Disfungsi Otonomik Somatoform, PPDGJ III, cetakan I, 1993, 216-217.

Gorman, JM, et al: Anxiogenic Effect Of CO2 And Hyperventilation In Patients With Panic Disorder, American Journal Psychiatry 151: 4, April 1994, 547 553.

Gorman, JM, et al : Respons To Hyperventilation in a Group Of Patients With Panic Disorder, American Journal Psychiatry 147:7, July 1984, 857- 861

Goldberg,J: Panic Disorder as a Chronic Illness, Online Coverage from the $149^{\text {th }}$ Annual Meeting of the American Psychiatric Association May 5-8, 1996, http:/ /medscape.com./Medscape/CNO/1996/APA/APA05.07.96/APA15a-5.7.96.html, January,1,1,1997.

Griffith, HW: Hyperventilation Syndrome ( Panic Attack ), Complete GuidetoPediatric Symptoms, Illness\&Medications,1989,http:/ /208.229.231.93/ health/Library/pedillsymp/pedillsymp220.html.

Gelder, M, et al: Anxiety, Obsessive-compulsive, and dissosiative disorders, Oxford Textbook of Psychiatry, $3^{\text {rd }}$ ed, 1996, 178.

Hanke, N: Hyperventilation Syndrome, Handbook Of Emergency Psychiatry, Copyright 1984.

Kaplan,H I, Sadock, BJ: Hyperventilation Syndrome, Respiratory Disorder, Comprehensive Textbook Of Psychiatry/ VI, vol 2, $6^{\text {th }}$ ed, 1501-1503.

Kaplan and Saddock's: Hyperventilation Syndrome, Synopsis Of Psychiatry, $7^{\text {th }}$ ed, 1994: 760.

Ley: Lecture 7: Anxiety Disorders: Etiology Biological Factors, AbnormalPsychology,http://ubcounseling. buffalo.edu/Abpsy/lecture7.html, 1987:p 197.

Michelson, D, et al: Outcome Assessment and Clinical Improvement in Panic Disorder: Evidence From a Randomized Controlled Trial of Fluoxetine and Placebo, American Journal Psychiatry 155:11, November 1998, 1570-1576.

Newton,EW:HyperventilationSyndrome,emedicine,http:/ /www.emedicine.com/emerg/topic270.htm, 1999.

Scully, JH: Hyperventilation Syndrome, Psychiatry, $3^{\text {rd }}$ edition, InfoMed, 1996, 176.

Saunders, WB: Hyperventilation Syndrome, Modern Clinical Psychiatry, $10^{\text {th }}$ ed, 1982, 584.

Woods, S.W, et al: Carbon Dioxide Sensitivity In Panic Anxiety, Archive General Psychiatry 43, September 1986, 900- 909.

Wilson,D: Intracranial Pressure/ Physiology of hyperventilation, picuBOOK an on-line resource for pediatric critical care, http://pedsccm.wustl.edu/All-Net/ english/neurpage/protect/vent-3.htm, 1999.

Web Psychiatry Club: Cardiovascular Sign During Panic Attacks, Mental Health Self-Help Corner, , File:// A: $\backslash$ Mental And Emotional Health Cardiovascular Sign During Panic Attacks.htm, January,1,1997.

Web Psychiatry Club: Cardiovascular Risk in Panic Disorder, Mental Health Self-Help Corner, File:// A: \Mental And Emotional Health Cardiovascular risk in Panic Disorder .htm,January,1,1997.
Web Psychiatry Club: Panic Disorder And Cardiovascular Problems, Mental Health Self- Help Corner, File/ /A: \Mental and Panic disorder and cardiovascular problem. Htm, January,1,1997

Web Psychiatry Club: Panic Disorder And Cardiovascular Risk: Conclusion, Mental Health Self-Help Corner, File://A: \Mental And Emotional Health Panic Disorder And Cardiovascular Risk Conclusion.httm, January,1,1997. 